\title{
A Study on the Effect of Construction Safety Accidents on Company Image and Consumer Needs
}

\author{
Yoonseok Shin1,a and Gwang-Hee Kim2,b \\ 1Dept. of Plant \& Architectural Engineering, Kyonggi University, Suwon, \\ Gyeonggi 443-760, Republic of Korea \\ 2Dept. of Plant \& Architectural Engineering, Kyonggi University, Suwon, \\ Gyeonggi 443-760, Republic of Korea (Corresponding Author) \\ ashinys@kgu.ac.kr,bghkim@kgu.ac.kr
}

\begin{abstract}
More and more consumers are giving a higher weight to the corporate image of the construction company when they purchase apartments. To keep the construction economy at a certain level, it is important to secure and satisfy these consumers, yet there have been few studies performed on this topic. Therefore, this study aims to analyze the effect safety accidents have on corporate image, and on the purchase intent of consumers. A questionnaire survey was conducted on 90 residents in their 20s and older, and from the results it was concluded that safety accidents have an impact on the direct and indirect losses of construction companies.
\end{abstract}

Keywords: Construction safety accident, Social responsibility, Company image, Consumer desire

\section{Introduction}

The number of consumers who try to respond to social responsibility of companies more actively through purchases is on the rise.[1] However, when a construction safety accident occurs before purchasing an apartment, there is an implication that the accident will have an adverse impact on consumer loyalty due to consumer dissatisfaction, which is incongruent with the emotion of the consumers after purchase.[2] Therefore, this study aims to define the type of safety accident that affects a company's image and clarify the examples of such a safety accident, and to measure the influence of these factors on the purchase intent, company image, and brand power. Thus, in this study an analysis was performed on the impact of a safety accident at a construction site on the company image and purchase intent of consumers based on previous studies. To do this, 90 residents in their 20s or older were surveyed through a questionnaire. 


\section{Theoretical review of the company image and the purchase intent of consumers}

In previous studies of the company image, Kotler(1994) defined a brand as a synthesis of the logo, symbol, registered product and package design used to differentiate a product or service of a company from that of competitors. In terms of previous studies on the purchase needs of consumers, most have been conducted on the behavioral intent in order to address the limitation of the expectation of consumer action.[3] Walters \& Paul(1974) indicated that the purchase intent is a decision-making process of what service to purchase, and when, where, how and from whom the service is purchased.[4] Sternthal\&Craig (1982) claimed that the purchase intent is related with the examination of the decision-making process of consumers and the consumers' choice and usage of the product or service.[5] In addition, Kallat\&Blackwell(1978) contended that a consumer's action includes the decision-making or personal action directly related with the acquisition of a product or service.[6]

\section{An analysis of the brand image and the purchase intent in a safety accident scenario}

The socially responsible activities of companies give a positive image to a brand, and also have an impact on the final decision-making step of the purchase. Overall, socially responsible activities may contribute to facilitation of the purchase intent.

This study examines how a safety accident affects the brand image upon the purchase of an apartment(a townhouse). Therefore, the relationship between the level of exposure of consumer to the media and the awareness of an apartment brand was clarified, as well as the relationship between the awareness of an apartment brand and the purchase. Based on the review of the previous studies, the hypotheses of this study were set as follows. First, the company image is changed by a safety accident. Second, the purchase intent of consumers is changed by a safety accident. Third, there is a positive relationship between the awareness of apartment brand and the purchase intent for an apartment brand.

\section{Consumer awareness of a company image}

Before examining the impact of a safety accident on the company image, positive attitude, high purchase intent, and brand reliability of a specific brand consumers have purchased for a certain period of time were examined. The following factors were surveyed.

Table 1. Questions on the elements of a company image

Element Question




\begin{tabular}{|c|c|}
\hline $\begin{array}{l}\text { Brand } \\
\text { preference }\end{array}$ & $\begin{array}{l}\text { "When it comes to this company, a stable image comes up." } \\
\text { "When it comes to this company, a friendly image comes up." }\end{array}$ \\
\hline $\begin{array}{l}\text { Brand } \\
\text { prestige }\end{array}$ & "When it comes to this company, a prestige image comes up." \\
\hline $\begin{array}{l}\text { Brand } \\
\text { reliability }\end{array}$ & $\begin{array}{l}\text { "When it comes to this company, I want to purchase a product." } \\
\text { "When it comes to this company, a reliable image comes up." }\end{array}$ \\
\hline
\end{tabular}

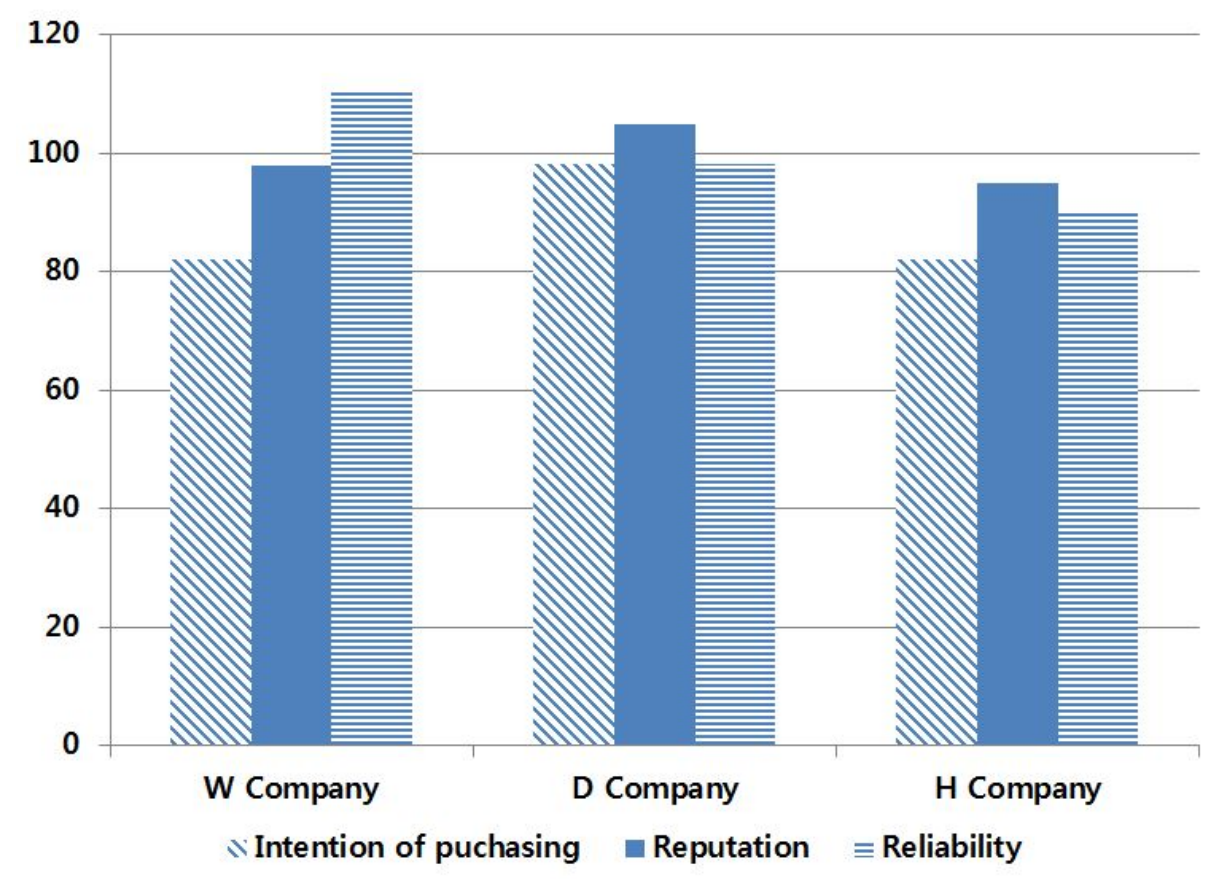

Figure 1. Survey results by factor

\section{Consumer awareness of safety accidents}

The respondents were as follows. To the question on whether the respondent considered the brands when planning to purchase an apartment, 7 respondents (7.8\%) answered “never,” 35 (38.9\%) “hardly,” 23(25.7\%) “moderately,” 29 (32.2\%) “considerably,” and 1 (1.1\%) "extremely.” To the question on whether 
the respondent has an intent to use a product of the company in the future, 3 respondents (3.3\%) said "never," 15 (16.7\%) "hardly," 39 (43.3\%) "moderately," 29 (32.2\%) "considerably," and 4 (4.5\%) "extremely." To the question on whether the respondent wuld recommend a product of the company to others, 24 respondents (26.7\%) repsonded "hardly,” 33 (36.7\%) "moderately,” 28 (31.1\%) "considerably," and 5 (5.5\%) "extremely."

Table 2. Factors measured by awareness component according to safety accident

\begin{tabular}{|c|c|}
\hline Factor & Question \\
\hline $\begin{array}{l}\text { Impact of a brand } \\
\text { on consumers }\end{array}$ & $\begin{array}{c}\text { "I considered the company brand at the decision-making of } \\
\text { purchase." }\end{array}$ \\
\hline $\begin{array}{l}\text { Re-purchase intent } \\
\text { of consumers }\end{array}$ & $\begin{array}{l}\text { "I have an intent to use the product of this company(apartment, or } \\
\text { townhouse) in the future" }\end{array}$ \\
\hline $\begin{array}{l}\text { Purchase intent after the } \\
\text { completion with no accident }\end{array}$ & $\begin{array}{l}\text { "I will recommend the product of this company(apartment, or } \\
\text { townhouse) to others." }\end{array}$ \\
\hline $\begin{array}{l}\text { Purchase intent after the } \\
\text { completion with an accident }\end{array}$ & $\begin{array}{c}\text { "I have an intent to purchase a product of the company that had an } \\
\text { safety accident } \\
\text { in the future." }\end{array}$ \\
\hline
\end{tabular}

\section{Relationship between the consumer awareness and the purchase intent for an apartment brand}

To the question on whether the company image has raised thanks to no accident, 0 respondent $(0 \%)$ answered "never," 5(5.5\%) "hardly,” 24(26.7\%) “moderately," 45(50\%) “considerably,” and 16(17.8\%) "extremely." In addition, to the question on whether the image of the company feels better than that of other companies thanks to no accident, 1 respondent(1.1\%) answered "never," 8(8.9\%) “hardly,” 28(31.1\%) “moderately,” 43(47.8\%) “considerably," and 10(11.1\%) "extremely."

Table 3. Questions by factor for the purchase intent and consumer awareness of the apartment brand

\section{Factor}

\section{Question}


Perceived image

Changes in image

Perceived image

Changes in image
The image has improved compared with the existing one.

The company image feels better than others.

It impaired the existing image of the company.

The company image feels worse than others

\section{Conclusion}

The results support the hypotheses that a safety accident has an adverse effect on company image, and that the consumers' purchase needs decline according to the severity of safety accidents. Most respondents to the survey drew the conclusion that a construction safety accident can have a serious influence on the company image, as other accidents do. In addition, the safety accident has a considerable impact on the indirect loss afterward along with the short-term direct loss. Therefore, to prevent a negative effect on the company image, the consumers' purchase rate, and profitability, companies needs to make an effort to decrease the number of safety accidents. Based on the findings of this research, a more concrete plan for reducing safety accidents should be proposed in the future.

\section{Acknowledgement}

This research was supported by Basic Science Research Program through the National Research Foundation of Korea(NRF) funded by the Ministry of Education. (2012R1A1A1042693)

\section{References}

[1] Min GS and Y JO, A Study of Factors Impact to the Purchase Intentions of Apartment, Journal of Residention Environment Institute of Korea, Vol. 9, No. 2, pp. 87-101 (2011)

[2] Yoo YJ, A Study on the Influence of apartment Brand Image on Customers' Apartment Buying Intention, Sangmyung University [Dissertation] (2011)

[3] Shin HC and Yoo SY, A Study on The Relationship among Customer's Knowledge, Image, and Service Satisfaction: Based on Communication Perspective, The Journal of Political Science \& Communication, Vol. 11, No. 1, pp. 299-319 (2008) 
[4] Lee YM and Kwon OJ, A Study on the Brand Image Intergration of Apartment By Residents' Evaluation, Journal of Housing Institute of Korea, Vol. 20, No. 2, pp. 87-99 (2009)

[5] Jang TW, A Study of the Structural Relationships Among Attitude Toward Advertisements, Corporate Image, SERVPERF and Customer Loyalty of Service Firms, Journal of Korean Society for Journalism \& Communication Studies, Vol. 43, No. 3, pp. 353-389 (2002)

[6] Park KN and Kim GU, An Empirical Study on the Effects of Web Service Quality on Corporation Image and Purchase Intent, Journal of Consumer Studies, Vol. 12, No. 3, pp. 1-27 (2009) 